\title{
Malignant Skull Neoplasm
}

National Cancer Institute

\section{Source}

National Cancer Institute. Malignant Skull Neoplasm. NCI Thesaurus. Code C155790.

A primary or metastatic malignant neoplasm that affects the bones and structures of the skull. 